\title{
Effective synthesis of 5-amino-1-pentanol by reductive amination of biomass-derived 2-hydroxytetrahydropyran over supported $\mathrm{Ni}$ catalysts
}

\author{
Xuemei Li †, Junying Tian †, Hailong Liu, Congkui Tang, Chungu Xia, Jing Chen \#, Zhiwei Huang * \\ State Key Laboratory for Oxo Synthesis and Selective Oxidation, Suzhou Research Institute of LICP, Lanzhou Institute of Chemical Physics (LICP), \\ Chinese Academy of Sciences, Lanzhou 730000, Gansu, China
}

\section{A R T I C L E I N F O}

\section{Article history:}

Received 1 September 2019

Accepted 10 October 2019

Published 5 April 2020

\section{Keywords:}

Ni catalyst

Reductive amination

Dihydropyran

5-Amino-1-pentanol

Structure-performance relationship

\begin{abstract}
A B S T R A C T
A highly efficient and green process was developed for the synthesis of useful 5-amino-1-pentanol (5-AP) from biomass-derived dihydropyran by coupling the in situ generation of 5-hydroxypentanal (5-HP, via the ring-opening tautomerization of 2-hydroxytetrahydropyran (2-HTHP)) and its reductive amination over supported $\mathrm{Ni}$ catalysts. The catalytic performances of the supported $\mathrm{Ni}$ catalysts on different oxides including $\mathrm{SiO}_{2}, \mathrm{TiO}_{2}, \mathrm{ZrO}_{2}, \gamma-\mathrm{Al}_{2} \mathrm{O}_{3}$, and $\mathrm{MgO}$ as well as several commercial hydrogenation catalysts were investigated. The $\mathrm{Ni} / \mathrm{ZrO}_{2}$ catalyst presented the highest 5 -AP yield. The characterization results of the oxide-supported $\mathrm{Ni}$ catalysts showed that the $\mathrm{Ni} / \mathrm{ZrO}_{2}$ catalyst possessed high reducibility and a high surface acid density, which lead to the enhanced activity and selectivity of the catalyst. The effect of reaction parameters on the catalytic performance of the $\mathrm{Ni} / \mathrm{ZrO}_{2}$ catalyst was studied, and a high 5 -AP yield of $90.8 \%$ was achieved in the reductive amination of 2-HTHP aqueous solution under mild conditions of $80^{\circ} \mathrm{C}$ and $2 \mathrm{MPa}_{2}$. The stability of the $\mathrm{Ni} / \mathrm{ZrO}_{2}$ catalyst was studied using a continuous flow reactor, and only a slight decrease in the 5-AP yield was observed after a 90-h time-on-stream. Additionally, the reaction pathways for the reductive amination of 2-HTHP to synthesize 5-AP were proposed.
\end{abstract}

(C) 2020, Dalian Institute of Chemical Physics, Chinese Academy of Sciences. Published by Elsevier B.V. All rights reserved.

\section{Introduction}

Nitrogen-containing compounds, particularly primary amines, are among the most important intermediates in the chemical industry with wide applications in the synthesis of polymers, pharmaceuticals, agrochemicals, dyes, and surfactants [1-3]. Nowadays, the general commercial routes for primary amine synthesis are the direct amination of alkyl halides or epoxides with ammonia, and the hydrogenation of nitriles or amides $[2,4]$. These processes generally suffer from high cost due to the lack of organic feedstocks with special functional group(s) or the generation of large amounts of waste. Therefore, much attention has been paid to the development of new catalytic processes for the efficient and sustainable production of primary amines [2,4-9].

Due to the readily available alcohols from not only the coal

\footnotetext{
* Corresponding author. Tel: +86-731-4968070; E-mail: zwhuang@licp.cas.cn

\# Corresponding author. Tel: +86-731-4968068; E-mail: chenj@licp.cas.cn

+ These authors contributed equally to this work.

This work was supported by the National Natural Science Foundation of China (21872155, 21473224), Cooperation Foundation of Dalian National Laboratory for Clean Energy (DNL 180303), Key Research Project of Frontier Science of Chinese Academy of Sciences (QYZDJ-SSW-SLH051), the Youth Innovation Promotion Association, CAS (2016371), and the Suzhou Science and Technology Development Plan (SYG201626). DOI: S1872-2067(19)63471-6 | http://www.sciencedirect.com/science/journal/18722067 | Chin. J. Catal., Vol. 41, No. 4, April 2020
} 
and petroleum industry but also renewable biomass, the direct amination of alcohols has been developed for the production of primary amines in recent years [2,4,10-12]. The direct amination of alcohols is widely considered to be proceeded by the borrowing hydrogen mechanism $(\mathrm{BH}$, Scheme 1$)$, and water is generated as the main byproduct [2,4,10-13]. Nonetheless, this process generally requires high reaction temperatures in the range of $150-250{ }^{\circ} \mathrm{C}$, owing to the dehydrogenation of $\mathrm{C}-\mathrm{OH}$ over metal catalysts usually occurred at a high temperature (Scheme 1, Step 1) [2]. Such a high temperature favors the generation of many byproducts, e.g., secondary and tertiary amines, and other nitrogen-containing heterocyclic compounds [2]. Differently, the direct reductive amination of aldehydes or ketones with ammonia does not require the dehydrogenation of $\mathrm{C}-\mathrm{OH}$. Thus, this provides an attractive approach to the synthesis of primary amines with high selectivity at temperatures $\leq 120^{\circ} \mathrm{C}[2,3,9]$.

It is known that carbonyl intermediates are usually generated during the preparation of alcohols (including diols) by transforming renewable lignocellulose and its derived platform molecules [9,14-16]. Therefore, the coupling of the formation of renewable aldehydes or ketones and their reductive amination may shed light on the sustainable synthesis of amines with high efficiency [2,8,9,14]. For instance, Zhang and coworkers [9] recently reported the first example of the direct conversion of cellulose into highly useful ethanolamines by a two-step approach: cellulose conversion to glycolaldehyde, followed by reductive amination. Ethanolamine with $10 \%$ yield was obtained from cellulose over a $\mathrm{Ru} / \mathrm{ZrO}_{2}$ catalyst at a low temperature of $75{ }^{\circ} \mathrm{C}$, and a high (93\%) ethanolamine yield could be achieved using glycolaldehyde as a reactant. Sels et al. [8] reported a new process for the efficient synthesis of short amines from carbohydrates by reductive aminolysis of the short carbonyl intermediates from the enzymatic retro-aldol $\mathrm{C}-\mathrm{C}$ bond scission of the sugar molecule. Valuable bio-based amines with yields of up to $87 \%$ were attained in one step at a temperature below $132{ }^{\circ} \mathrm{C}$.

In this work, we report on the efficient synthesis of 5-amino-1-pentanol (5-AP), an important amino alcohol that can be used in the synthesis of anti-inflammatory drugs and anticancer drugs, from biomass-derived dihydropyran by coupling the in situ generation of 5-hydroxypentanal (5-HP) and its reductive amination over supported $\mathrm{Ni}$ catalysts under mild conditions (Scheme 2, Route B). 5-HP is a ring-opened tauto-

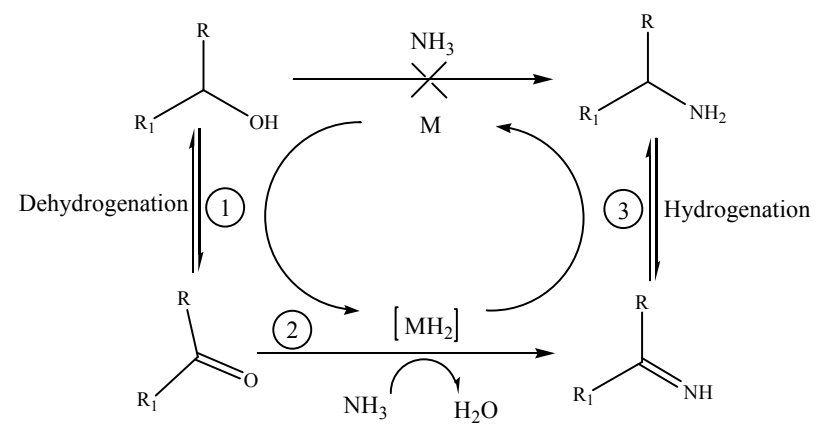

Scheme 1. Direct amination of alcohols with ammonia by the borrowing hydrogen mechanism.

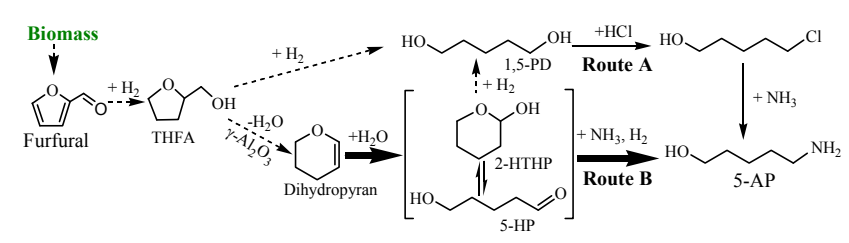

Scheme 2. Synthesis of 5-AP from biomass-derived 1,5-pentanediol (Route A) and dihydropyran (Route B, large black arrow).

mer of 2-hydroxytetrahydropyran (2-HTHP), and the equilibrium composition of 5-HP at room temperature $\left(25^{\circ} \mathrm{C}\right)$ is about $2.4 \%$ [17]. The ring-opening tautomerization is an endothermic reaction; consequently, the transformation of 2-HTHP to 5-HP increased with increasing temperature [17]. The compound, 2-HTHP, can be readily synthesized by the autocatalytic hydration of biomass-derived dihydropyran with a yield of up to $92 \%$ [18]. In comparison with the production of 5-AP from 1,5-PD by its reaction with concentrated hydrogen chloride, followed by amination with ammonia (Scheme 2, Route A) [19], the synthesis of 5-AP from dihydropyran (Scheme 2, Route B) is not only more efficient but also much cleaner (almost no waste generation). Moreover, a higher 5-AP total yield of $\sim 82 \%$ could be obtained by this new route in contrast to the $66 \%$ yield by the 1,5-PD route. The catalytic performances of the supported $\mathrm{Ni}$ catalysts on different oxides including $\mathrm{SiO}_{2}, \mathrm{TiO}_{2}, \mathrm{ZrO}_{2}, \gamma-\mathrm{Al}_{2} \mathrm{O}_{3}$, and $\mathrm{MgO}$ were investigated and compared with a serial of commercial hydrogenation catalysts, including $\mathrm{CuCr}_{2} \mathrm{O}_{4}$, Raney $\mathrm{Ni}$, and carbon-supported noble metals of $\mathrm{Ru}, \mathrm{Pd}, \mathrm{Pt}$, and $\mathrm{Rh}$. $\mathrm{Ni} / \mathrm{ZrO}_{2}$ was found to present the highest 5 -AP yield among the catalysts investigated, and the high performance of this catalyst was discussed based on the characterization results of the oxide supported Ni catalysts. In addition, the reaction parameters including the reaction temperature, $\mathrm{H}_{2}$ pressure, time, and 2-HTHP to $\mathrm{NH}_{3}$ molar ratio were examined, and possible reaction pathways for the synthesis of 5-AP from 2-HTHP were proposed.

\section{Experimental}

\subsection{Materials}

The $\mathrm{SiO}_{2}$ support, $\mathrm{Al}_{2} \mathrm{O}_{3}$ support, $\mathrm{MgO}$ support, $\mathrm{Ru} / \mathrm{C}$ (5.0 wt $\%$, reduced, $50 \%$ water wet), Pt/C (10.0 wt $\%$, reduced, 50\% water wet), $\mathrm{Pd} / \mathrm{C}$ (10.0 wt $\%$, reduced, $50 \%$ water wet), 1,5-pentanediol (98\%), and dihydropyran (99\%) were purchased from Alfa Aesar. The $\mathrm{TiO}_{2}$ support and $\mathrm{ZrO}_{2}$ support were obtained from Xuan Cheng Jing Rui New Material Co., Ltd. The Rh/C (5 wt\%) catalyst was purchased from Innochem (Beijing) Technology Co., Ltd. The reagents, 1,2-pentanediol (98\%) and 5-amino-1-pentanol (95\%), were obtained from Aladdin Chemical Reagent Co. Ltd. The compound, 2-hydroxytetrahydropyran (90\%), was purchased from ACROS. $\mathrm{H}_{2}$ (99.999\%) and $\mathrm{He}$ (99.999\%) were obtained from the Lanzhou Lanmei Cryogenic Products Co., Ltd., China. A 10 vol\% $\mathrm{NH}_{3}$ in nitrogen solution was purchased from Shangdong Tianhai Co., Ltd. The aqueous solution of 2-HTHP with 21.8 wt $\%$ ( $90.8 \%$ yield) was synthesized by the autocatalytic hydra- 
tion of the dihydropyran method [18]. The hydration reaction was carried out in a $2 \mathrm{~L}$ autoclave equipped with a mechanical stirrer. After adding $100 \mathrm{~g}$ of dihydropyran and $400 \mathrm{~g}$ of DI water, the autoclave was sealed and pressured with nitrogen to $2 \mathrm{MPa}$. Thereafter, the autoclave was heated to $100{ }^{\circ} \mathrm{C}$ for $1 \mathrm{~h}$. All other chemical reagents were of analytical grade and were used without further purification.

\subsection{Catalyst preparation}

Oxide supports supported Ni catalysts with $15 \mathrm{wt} \% \mathrm{Ni}$ were prepared by a wetness co-impregnation method [20]. Typically, a calculated amount of $\mathrm{Ni}\left(\mathrm{NO}_{3}\right)_{2} \cdot 6 \mathrm{H}_{2} \mathrm{O}$ was dissolved in deionized water and ethylene glycol at a molar ratio of $\mathrm{Ni}$ : $\mathrm{EG}=1: 1$, and subsequently impregnated onto the oxide supports with stirring at room temperature for $2 \mathrm{~h}$. Thereafter, the obtained samples were dried at $110^{\circ} \mathrm{C}$ for $12 \mathrm{~h}$ and calcined at $450{ }^{\circ} \mathrm{C}$ for $2 \mathrm{~h}$ in a nitrogen atmosphere. The obtained calcined samples were denoted as $\mathrm{Ni} / \mathrm{SiO}_{2}, \mathrm{Ni} / \mathrm{Al}_{2} \mathrm{O}_{3}, \mathrm{Ni} / \mathrm{MgO}, \mathrm{Ni} / \mathrm{TiO}_{2}$, and $\mathrm{Ni} / \mathrm{ZrO}_{2}$ according to the supports used.

\subsection{Catalyst characterization}

The Brunauer-Emmett-Teller (BET) surface area and average pore diameter of the supported Ni catalysts were determined using a TriStar II 3020 (Micromeritics) surface area and porosity analyzer. Prior to the measurement, the samples were pretreated in a nitrogen flow at $300{ }^{\circ} \mathrm{C}$ for $4 \mathrm{~h}$. A transmission electron microscope (TEM, TF20, operated at $200 \mathrm{kV}$ ) was used to observe the shape and size of the Ni particles of the catalysts, and the catalysts were reduced at $450{ }^{\circ} \mathrm{C}$ for $3 \mathrm{~h}$ before being dispersed on the copper mesh for testing. The particle size dispersion of the $\mathrm{Ni}$ particles was statistically obtained from the TEM micrograph by counting more than 200 particles. The X-ray powder diffraction (XRD) patterns of the samples were obtained on a Rigaku D/MAX-2400 diffractometer in reflection mode ( $\mathrm{Cu} K_{\alpha}$ radiation) at a scanning rate of $10^{\circ} \mathrm{s}^{-1}$ in the $2 \theta$ range of $10^{\circ}-90^{\circ}$. X-ray photoelectron spectroscopy (XPS) was conducted on an ESCALAB250xi spectrometer with a monochromatized Al $K_{\alpha}$ source ( $h v=1486.6 \mathrm{eV}$ ) at a constant analyzer pass energy of $20 \mathrm{eV}$. All binding energies were calibrated with the $\mathrm{C} 1 \mathrm{~s}(284.6 \mathrm{eV})$ as an internal standard. The reduced catalysts were treated in a flow of $1 \% \mathrm{O}_{2}$ in a nitrogen atmosphere for $2 \mathrm{~h}$ at room temperature before carrying out the XRD and XPS measurements.

$\mathrm{H}_{2}$ temperature-programmed reduction $\left(\mathrm{H}_{2}\right.$-TPR) measurements were conducted on a Quantachrome automated chemisorption analyzer (ChemBET pulsar TPR/TPD) to analyze the reducibility of the catalysts. In a typical process, $40 \mathrm{mg}$ of the calcined catalyst sample was placed in a quartz tube reactor and subsequently flushed with high purity He at $200{ }^{\circ} \mathrm{C}$ for $1 \mathrm{~h}$ to remove water and other contaminants. After cooling to room temperature, a gas mixture containing $10 \mathrm{vol} \% \mathrm{H}_{2}$ in Ar was passed through the sample at a total flow rate of $30 \mathrm{~mL}$ min $^{-1}$. The $\mathrm{H}_{2}$ consumption was recorded by a thermal conductivity detector (TCD), while the temperature was increased to $800^{\circ} \mathrm{C}$ at a ramping rate of $10^{\circ} \mathrm{C} \mathrm{min}^{-1}$.
$\mathrm{NH}_{3}$ temperature-programmed desorption ( $\left.\mathrm{NH}_{3}-\mathrm{TPD}\right)$ measurements were carried out with a Huasi DAS-7200 automatic chemical adsorption instrument to analyze the acidity of the catalysts. Prior to the measurements, the calcined sample $(0.20 \mathrm{~g})$ was reduced with $5 \% \mathrm{H}_{2} / 95 \% \mathrm{Ar}\left(30 \mathrm{~mL} \mathrm{~min}^{-1}\right)$ at 450 ${ }^{\circ} \mathrm{C}$ for $2 \mathrm{~h}$. After reduction, the sample was cooled to $100^{\circ} \mathrm{C}$, and then $10 \% \mathrm{NH}_{3} / 90 \% \mathrm{~N}_{2}$ was supplied into the reactor at $30 \mathrm{~mL}$ $\min ^{-1}$ for $1 \mathrm{~h}$. After $\mathrm{NH}_{3}$ adsorption, the system was purged with $\mathrm{He}\left(30 \mathrm{~mL} \mathrm{~min}^{-1}\right)$ for $1 \mathrm{~h}$, after which the temperature was increased from 50 to $800{ }^{\circ} \mathrm{C}$ at a rate of $10^{\circ} \mathrm{C} \mathrm{min}-1$. The $\mathrm{NH}_{3}$ desorption was monitored by a TCD.

\subsection{Catalytic test and product analysis}

The discontinuous 2-HTHP reductive amination reaction was carried out in a $100 \mathrm{~mL}$ stainless steel autoclave reactor at a stirring speed of $800 \mathrm{rpm}$. Prior to the reaction, the calcined $\mathrm{Ni}$ catalysts were reduced at $450{ }^{\circ} \mathrm{C}$ in pure $\mathrm{H}_{2}$ at a flow rate of

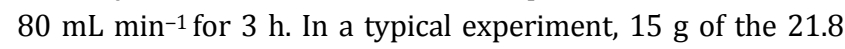
wt\% 2-HTHP aqueous solution together with $15 \mathrm{~g}$ of the 25 wt $\%$ concentrated ammonia solution was added into the reactor. The reduced catalyst, which was sealed in a $\mathrm{H}_{2}$ atmosphere, was quickly tipped into the reaction solution to avoid oxidation. After flushing the tightly sealed reactor with $\mathrm{H}_{2} 3$ times, the reactor was initially pressurized with $\mathrm{H}_{2}$ to $2.0 \mathrm{MPa}$, and then heated to $80^{\circ} \mathrm{C}$, a temperature that was maintained during the reaction.

The stability of the selected catalyst was studied using a continuous flow reactor (length: $36 \mathrm{~cm}$, and inner diameter: 0.9 $\mathrm{cm})$ at $80^{\circ} \mathrm{C}$ and $3 \mathrm{MPa} \mathrm{H}$. The calcined catalyst ( $2.0 \mathrm{~g}$ ) with sizes of 20-40 meshes was embedded with quartz powders (20-40 meshes) in both sides of the catalyst bed. The catalyst was prereduced at $450{ }^{\circ} \mathrm{C}$ in pure $\mathrm{H}_{2}$ at atmospheric pressure and a flow rate of $80 \mathrm{~mL} \mathrm{~min}^{-1}$ for $3 \mathrm{~h}$. After cooling to the reaction temperature, the reactor was pressured to $3 \mathrm{MPa}$ with $\mathrm{H}_{2}$; afterward, a well-mixed solution of $21.8 \mathrm{wt} \%$ 2-HTHP aqueous solution and $25 \mathrm{wt} \%$ concentrated ammonia at a weight ratio of $1: 1$ was pumped into the reactor at a speed of $9 \mathrm{~g} \mathrm{~h}^{-1}$. The $\mathrm{H}_{2}$ to 2-HTHP molar ratio was 30 . Liquid samples were collected from a stainless-steel gas-liquid separator every 5 to $10 \mathrm{~h}$.

The reactant and liquid products were analyzed using a gas chromatograph (Agilent 7890A GC) equipped with an HP-5MS capillary column $(50 \mathrm{~m} \times 0.32 \mathrm{~mm} \times 2.0 \mu \mathrm{m})$. The temperatures of the injector and detector were 250 and $280{ }^{\circ} \mathrm{C}$, respectively. The temperature program was conducted as follows: initial temperature and time $=110{ }^{\circ} \mathrm{C}$ and $6 \mathrm{~min}$; final temperature and time $=260{ }^{\circ} \mathrm{C}$ and $10 \mathrm{~min}$; heating rate $=15^{\circ} \mathrm{C} \mathrm{min}-1$. The products were also identified on a GC-MS instrument (Agilent 7890A/5975C) equipped with an HP-5MS column. The detected liquid products were 5-amino-1-pentanol (5-AP), 1,5-pentanediol (1,5-PD), 5-imino-1-pentanol (5-IP), and 5-[(5-hydroxypentyl)imino]-1-pentanol (5-HPIP). The product 1,2-pentanediol (1,2-PD) was used as an internal standard for quantitative analysis. Due to the unavailability of the standards for 5-IP and 5-HPIP, their GC response factors were assumed to be identical and twice that of 5-AP, respectively. The conversion and product selectivity were calculated as follows: 
Table 1

Textural properties of Ni catalysts supported on different oxides.

\begin{tabular}{|c|c|c|c|c|c|c|}
\hline Catalyst & $\begin{array}{c}A_{\mathrm{BET}}{ }^{\mathrm{a}} \\
\left(\mathrm{m}^{2} \mathrm{~g}^{-1}\right)\end{array}$ & $\begin{array}{l}D_{\text {pore }}{ }^{\mathrm{b}} \\
(\mathrm{nm})\end{array}$ & $\begin{array}{c}\mathrm{Ni}^{0} \text { crystallite size }{ }^{\mathrm{c}} \\
\text { (nm) }\end{array}$ & $\begin{array}{c}\mathrm{Ni}^{0} \text { particle size }{ }^{\mathrm{d}} \\
(\mathrm{nm})\end{array}$ & $\begin{array}{l}\text { Acid amount e } \\
\left(\mathrm{mmol} \mathrm{g}^{-1}\right)\end{array}$ & $\begin{array}{c}\text { Acid density }{ }^{\mathrm{f}} \\
\left(\mu \mathrm{mol} \mathrm{m}{ }^{-2}\right)\end{array}$ \\
\hline $\mathrm{Ni} / \mathrm{MgO}$ & 171.4 & 10.7 & - & 4.5 & $<0.01$ & $<0.01$ \\
\hline $\mathrm{Ni} / \mathrm{SiO}_{2}$ & 78.5 & 11.0 & 6.3 & 3.7 & 0.15 & 1.91 \\
\hline $\mathrm{Ni} / \mathrm{TiO}_{2}$ & 82.4 & 11.9 & 10.4 & 10.0 & 0.27 & 3.28 \\
\hline $\mathrm{Ni} / \mathrm{Al}_{2} \mathrm{O}_{3}$ & 202.4 & 9.7 & - & 4.1 & 0.44 & 2.17 \\
\hline $\mathrm{Ni} / \mathrm{ZrO}_{2}$ & 29.1 & 22.9 & 11.0 & 12.6 & 0.12 & 4.24 \\
\hline
\end{tabular}

a Surface area calculated by the BET method. ${ }^{\mathrm{b}}$ Desorption average pore diameter calculated by the BJH method. ${ }^{\mathrm{c}}$ Calculated by the Scherrer equation through the Ni (111) diffraction peak. ${ }^{\mathrm{d}}$ Measured from TEM images. ${ }^{\mathrm{e}}$ Amount of the surface acidic site determined by $\mathrm{NH}_{3}-\mathrm{TPD}^{\mathrm{f}}{ }^{\mathrm{f}}$ Density of the surface acidic site estimated from the surface area of the catalysts and $\mathrm{NH}_{3}$-TPD results.

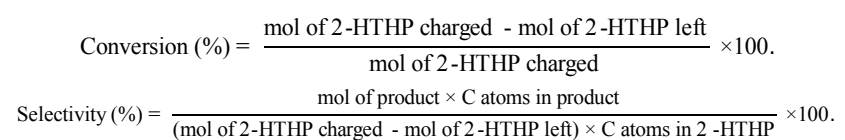

\section{Results and discussion}

\subsection{Characterization of catalysts}

The textural properties of the Ni catalysts supported on different oxides are listed in Table 1. The BET surface area of the calcined catalyst samples varied from 29.1 to $202.4 \mathrm{~m}^{2} \mathrm{~g}^{-1}$, decreasing in the order of $\mathrm{Ni} / \mathrm{Al}_{2} \mathrm{O}_{3}>\mathrm{Ni} / \mathrm{MgO}>\mathrm{Ni} / \mathrm{TiO}_{2}>\mathrm{Ni} / \mathrm{SiO}_{2}$ $>\mathrm{Ni} / \mathrm{ZrO}_{2}$. This difference could be ascribed to the intrinsic difference of the supports and the dispersion of $\mathrm{Ni}$ in the catalysts. The average pore diameters of the catalyst samples were all in the mesopore range of $9.7-22.9 \mathrm{~nm}$.

Fig. 1 shows the XRD patterns of the Ni catalysts supported on different oxides after calcination and reduction. For the calcined samples (Fig. 1(a)), no noticeable diffraction peaks of $\mathrm{NiO}$ could be observed in $\mathrm{Ni} / \mathrm{Al}_{2} \mathrm{O}_{3}$ and $\mathrm{Ni} / \mathrm{MgO}$, indicating that the $\mathrm{NiO}$ particles were very small or highly dispersed in these samples. The diffraction peaks of $\mathrm{NiO}$ with different intensities appeared in $\mathrm{Ni} / \mathrm{TiO}_{2}, \mathrm{Ni} / \mathrm{ZrO}_{2}$, and $\mathrm{Ni} / \mathrm{SiO}_{2}$. After reduction at 450 ${ }^{\circ} \mathrm{C}$ for $3 \mathrm{~h}$, the diffraction peaks of $\mathrm{NiO}$ disappeared, meanwhile the characteristic diffraction peaks of $\mathrm{Ni}^{0}$ appeared in the $\mathrm{Ni} / \mathrm{ZrO}_{2}$ and $\mathrm{Ni} / \mathrm{TiO}_{2}$ catalysts (Fig. 2(b)), indicating the reduction of $\mathrm{NiO}$ to $\mathrm{Ni}^{0}$. There were no diffraction peaks of $\mathrm{Ni}^{0}$ in the $\mathrm{Ni} / \mathrm{Al}_{2} \mathrm{O}_{3}$ and $\mathrm{Ni} / \mathrm{MgO}$ catalysts, and only a broad diffraction peak at around $2 \theta=44.4^{\circ}$ attributed to $\mathrm{Ni}^{0}$, was observed in $\mathrm{Ni} / \mathrm{SiO}_{2}$, revealing the high dispersion of $\mathrm{Ni}^{0}$ in these catalysts. The $\mathrm{Ni}^{0}$ crystallite sizes of the $\mathrm{Ni}$ catalysts supported on $\mathrm{SiO}_{2}$, $\mathrm{TiO}_{2}$, and $\mathrm{ZrO}_{2}$ were calculated to be $6.3-11.0 \mathrm{~nm}$ by the Scherrer equation (Table 1 ).

Fig. 2 displays the TEM images and particle size distributions of the Ni catalysts supported on different oxides. As can be seen, quasi-circular $\mathrm{Ni}$ particles with a mean particle size smaller than $5 \mathrm{~nm}$ were well dispersed in $\mathrm{Ni} / \mathrm{MgO}, \mathrm{Ni} / \mathrm{SiO}_{2}$, and $\mathrm{Ni} / \mathrm{Al}_{2} \mathrm{O}_{3}$. Differently, many relatively large particles were observed in the $\mathrm{Ni} / \mathrm{TiO}_{2}$ and $\mathrm{Ni} / \mathrm{ZrO}_{2}$ catalysts, and it is slightly difficult to discriminate the $\mathrm{Ni}$ particles from the oxide support. Based on the HRTEM analysis, some $\mathrm{Ni}^{0}$ nanoparticles were identified (Fig. S1). The average particle sizes of $\mathrm{Ni}$ in $\mathrm{Ni} / \mathrm{TiO}_{2}$ and $\mathrm{Ni} / \mathrm{ZrO}_{2}$ were around 10.0 and $12.6 \mathrm{~nm}$. The particle sizes obtained from the TEM measurements coincided with the results calculated well from the XRD patterns with the exception of $\mathrm{Ni} / \mathrm{SiO}_{2}$. The larger $\mathrm{Ni}^{0}$ crystallite size obtained from XRD for $\mathrm{Ni} / \mathrm{SiO}_{2}$ as compared with that from TEM was probably due to the bimodal size distribution of the $\mathrm{Ni}^{0}$ particles [21,22].
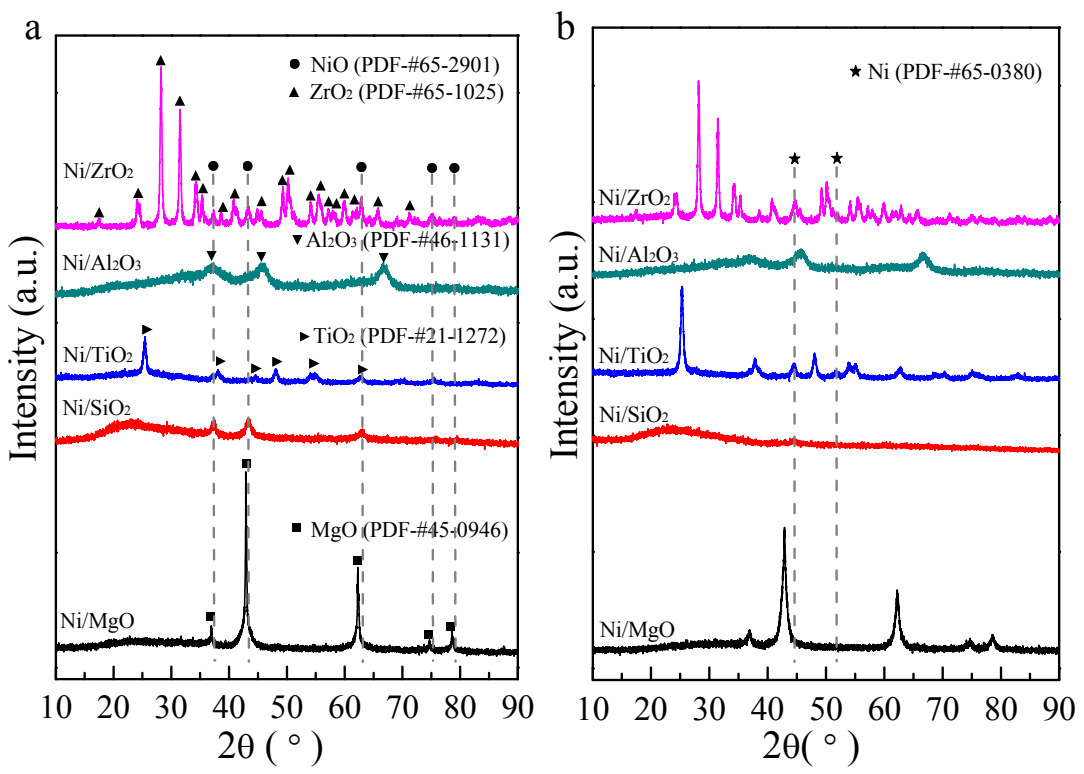

Fig. 1. XRD patterns of the Ni catalysts supported on different oxides. (A) After calcination; (B) After reduction. 

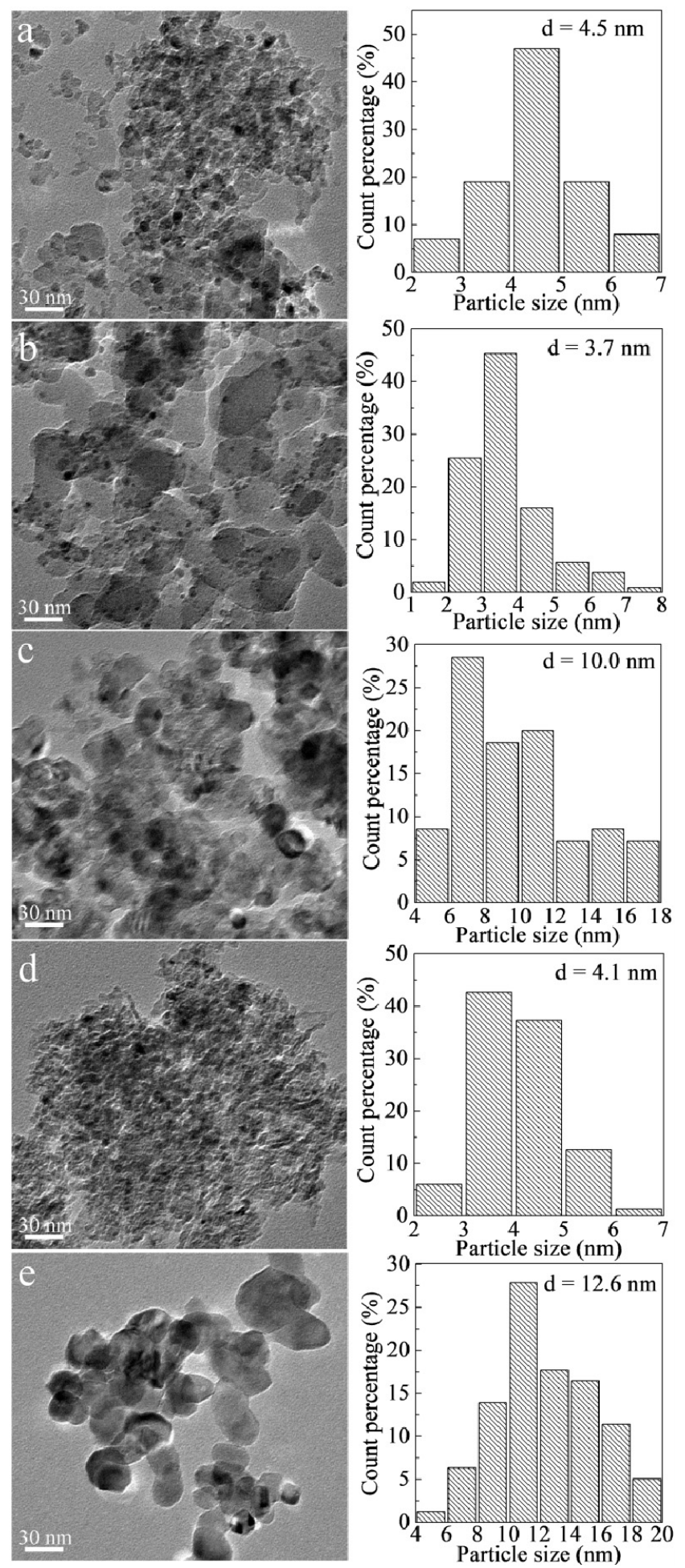

Fig. 2. TEM images and particles size dispersion of different $\mathrm{Ni}$ catalysts. (a) Ni/MgO; (b) $\mathrm{Ni} / \mathrm{SiO}_{2}$; (c) $\mathrm{Ni} / \mathrm{TiO}_{2}$; (d) $\mathrm{Ni} / \mathrm{Al}_{2} \mathrm{O}_{3}$; (e) $\mathrm{Ni} / \mathrm{ZrO}_{2}$.

Fig. 3 displays the $\mathrm{H}_{2}$-TPR profiles of the Ni catalysts supported on different oxides. As can be seen, the calcined samples generally presented three hydrogenation consumption peaks with the low-temperature peaks appearing at temperatures below $379{ }^{\circ} \mathrm{C}$, and the high-temperature peaks appearing at temperatures above $419{ }^{\circ} \mathrm{C}$. Both of the calcined $\mathrm{Ni} / \mathrm{ZrO}_{2}$ and $\mathrm{Ni} / \mathrm{TiO}_{2}$ samples showed reduction peaks below $470{ }^{\circ} \mathrm{C}$, while the other three samples showed high-temperature peaks at temperatures above $528{ }^{\circ} \mathrm{C}$ with that of $\mathrm{Ni} / \mathrm{MgO}$ appearing at temperatures above $700{ }^{\circ} \mathrm{C}$. This indicated that the reducible $\mathrm{Ni}$ species in $\mathrm{Ni} / \mathrm{ZrO}_{2}$ and $\mathrm{Ni} / \mathrm{TiO}_{2}$ appeared at a lower temperature, while those in $\mathrm{Ni} / \mathrm{MgO}$ appeared at a much higher temperature. Generally, NiO with small particle sizes or low interaction with the support could be reduced at low temperatures, while $\mathrm{Ni}^{2+}$ with strong metal-support interaction was reduced at relatively high temperatures $[23,24]$. Accordingly, the three reduction peaks from low to high temperature for the catalysts samples are probably associated with the reduction of small $\mathrm{NiO}$ particle sizes with low metal-support interactions, bulk $\mathrm{NiO}$ with larger sizes, and $\mathrm{Ni}^{2+}$ with relatively strong metal-support interactions, respectively. Evidently, the majority of the $\mathrm{Ni}$ species in the calcined $\mathrm{Ni} / \mathrm{Al}_{2} \mathrm{O}_{3}$ and $\mathrm{Ni} / \mathrm{MgO}$ are highly dispersed $\mathrm{Ni}$ particles in strong interaction with the support, while a large amount of bulk $\mathrm{NiO}$ was present in the calcined $\mathrm{Ni} / \mathrm{ZrO}_{2}$ and $\mathrm{Ni} / \mathrm{SiO}_{2}$. These findings are in agreement with the above XRD and TEM characterizations. The amount of $\mathrm{H}_{2}$ consumption for the catalysts decreased in the order of $\mathrm{Ni} / \mathrm{Al}_{2} \mathrm{O}_{3}>$ $\mathrm{Ni} / \mathrm{ZrO}_{2}>\mathrm{Ni} / \mathrm{SiO}_{2}>\mathrm{Ni} / \mathrm{TiO}_{2}>\mathrm{Ni} / \mathrm{MgO}$, roughly reflecting the amount of $\mathrm{Ni}^{2+}$ species that could be reduced to $\mathrm{Ni}^{0}$, which may affect the catalytic performance of the catalysts.

It has been reported that the surface acidity of the catalyst could promote the condensation of carbonyl groups and $\mathrm{NH}_{3}$ or amino groups to form imine intermediates [9,25]. $\mathrm{NH}_{3}-\mathrm{TPD}$ was carried out to determine the surface acidity of the different oxide-supported Ni catalysts. As shown in Fig. 4, the acid properties of the Ni catalysts were different from each other. Almost no noticeable $\mathrm{NH}_{3}$ desorption peak could be seen for $\mathrm{Ni} / \mathrm{MgO}$, indicating the rather low acidity of this catalyst. Two or three $\mathrm{NH}_{3}$ desorption peaks were observed in the range of 200-420 ${ }^{\circ} \mathrm{C}$ for the other four catalysts with those of the $\mathrm{Ni} / \mathrm{Al}_{2} \mathrm{O}_{3}$ being extremely high. The acid amount of the catalysts decreased in the order of $\mathrm{Ni} / \mathrm{Al}_{2} \mathrm{O}_{3}>\mathrm{Ni} / \mathrm{TiO}_{2}>\mathrm{Ni} / \mathrm{SiO}_{2}>\mathrm{Ni} / \mathrm{ZrO}_{2}>\mathrm{Ni} / \mathrm{MgO}$. The densities of the acidic sites of the catalysts (Table 1) show that the $\mathrm{Ni} / \mathrm{ZrO}_{2}$ catalyst exhibited the highest acidic site density among the five catalysts investigated.

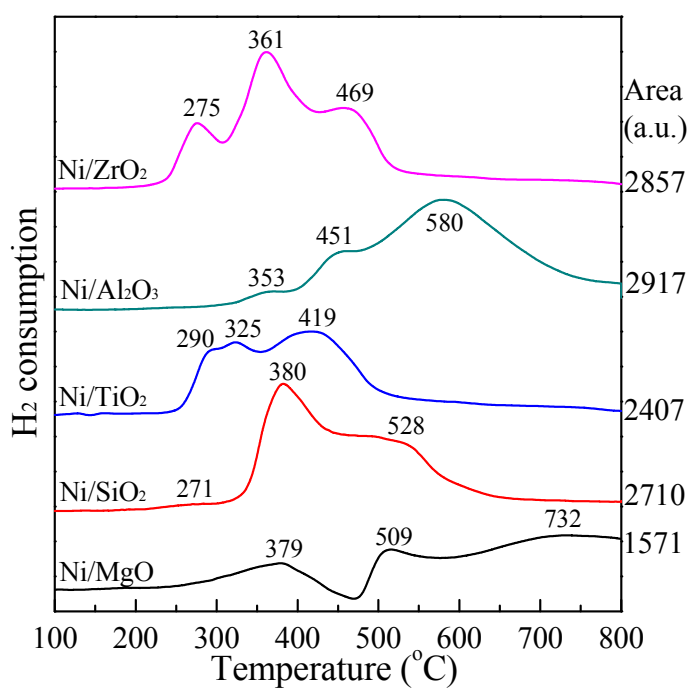

Fig. 3. $\mathrm{H}_{2}$-TPR profiles of different oxide-supported Ni catalysts. 


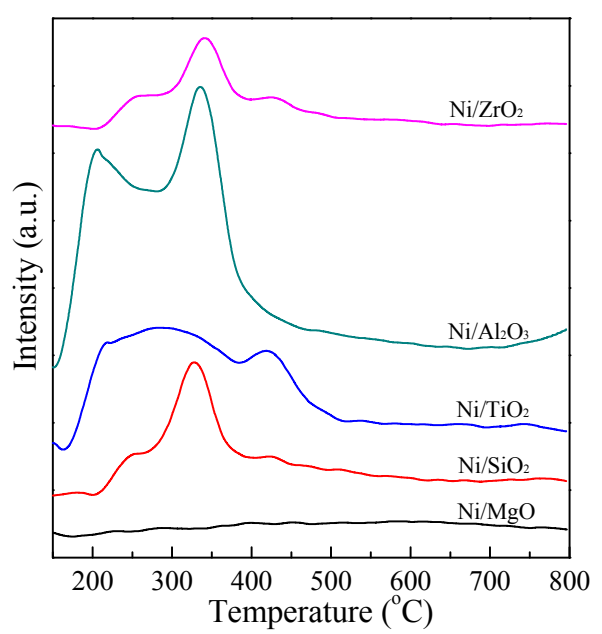

Fig. 4. $\mathrm{NH}_{3}$-TPD patterns of different oxide-supported $\mathrm{Ni}$ catalysts.

\subsection{Catalytic performance}

\subsubsection{Catalytic performance of different catalysts in the reductive amination of $2-H T H P$}

Table 2 shows the catalytic performance of different catalysts in the reductive amination of 2 -HTHP at $80^{\circ} \mathrm{C}$ and $2 \mathrm{MPa}$ $\mathrm{H}_{2}$. As can be seen, the conversion of 2-HTHP in all tests was considerably high $(>92 \%)$, indicating the high reactivity of 2-HTHP, which is in line with the previous studies by Brentzel et al. on the direct hydrogenation of 2-HTHP and its dimmers to produce 1,5-PD [17]. The conversion of 2-HTHP reached $100 \%$ even in the absence of a catalyst, while the amination product of 5-IP was the main detected product with a $29.5 \%$ selectivity (entry 1). The generation of the dimmers of 2-HTHP [17] and some other undetected byproducts might account for the low

Table 2

Catalytic performance of different catalysts toward the amination of the 2-HTHP aqueous solution prepared from dihydropyran a.

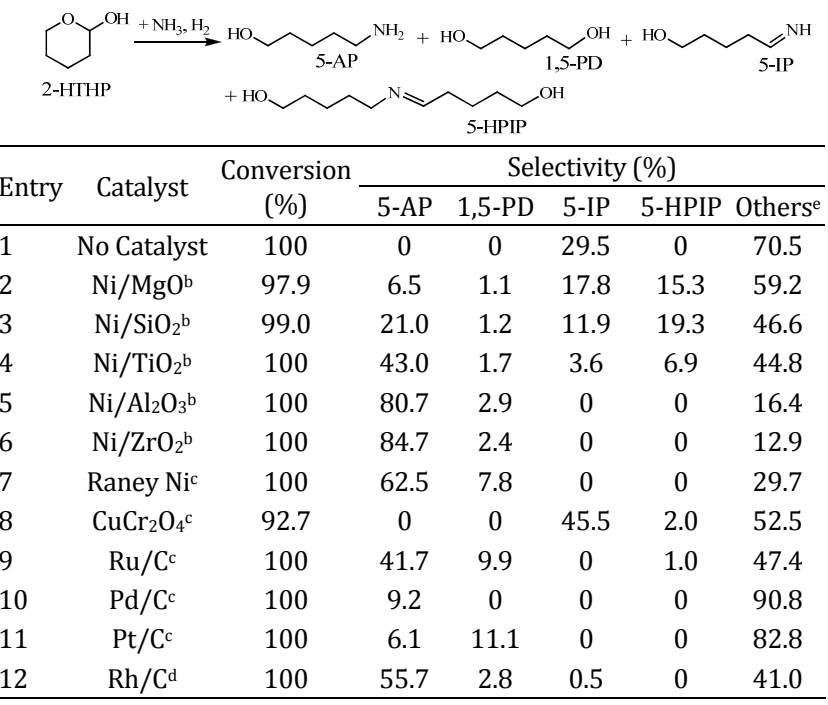

a Reaction conditions: $15 \mathrm{~g}$ of $21.8 \%$ 2-HTHP aqueous solution, $15 \mathrm{~g}$ of 25 wt $\%$ ammonia, $2 \mathrm{MPa} \mathrm{H}_{2}, 80{ }^{\circ} \mathrm{C}, 1$ h. b 0.33 g. c 0.5 g. d 0.25 g. e Including the dimmers of 2-HTHP and some undetected byproducts. carbon balance. The selectivity of the supported Ni catalysts toward 5-AP differs greatly depending on the supports, which increased in the order of $\mathrm{Ni} / \mathrm{MgO}<\mathrm{Ni} / \mathrm{SiO}_{2}<\mathrm{Ni} / \mathrm{TiO}_{2}<$ $\mathrm{Ni} / \mathrm{Al}_{2} \mathrm{O}_{3}<\mathrm{Ni} / \mathrm{ZrO}_{2}$, with the $\mathrm{Ni} / \mathrm{ZrO}_{2}$ catalyst exhibiting the highest selectivity of $84.7 \%$ (entries 2-6). All the supported $\mathrm{Ni}$ catalysts showed low selectivity toward 1,5-PD $(<3 \%)$, the byproduct from the direct hydrogenation of 5-HP (the ring-opened tautomer of 2-HTHP) [17,21]. The selectivity of the oxide-supported Ni catalysts toward 5-IP and 5-HPIP generally decreased in the opposite trend to that of 5-AP, and almost no 5-IP and 5-HPIP could be detected over the $\mathrm{Ni} / \mathrm{Al}_{2} \mathrm{O}_{3}$ and $\mathrm{Ni} / \mathrm{ZrO}_{2}$ catalysts with a high 5 -AP selectivity $(>80 \%)$.

For comparison, the catalytic performances of a variety of commercial hydrogenation catalysts including Raney $\mathrm{Ni}$, $\mathrm{CuCr}_{2} \mathrm{O}_{4}$, and the carbon-supported noble metals of $\mathrm{Ru}, \mathrm{Pd}, \mathrm{Pt}$, and $\mathrm{Rh}$ (entries 7-12). Only Raney $\mathrm{Ni}$ and $\mathrm{Rh} / \mathrm{C}$ showed moderate selectivity $(\sim 60 \%)$ toward 5 -AP, while others exhibited considerably low selectivity $(<42 \%)$ toward 5-AP. Evidently, the above findings indicate that $\mathrm{Ni} / \mathrm{ZrO}_{2}$ is a promising catalyst for this reaction. The high performance of the Ni catalysts in the 2-HTHP reductive amination is in line with previous studies, which reported that the Ni catalysts exhibit high activity in the reductive amination of carbonyl-containing compounds $[8,26,27]$ and the amination of alcohols by the $\mathrm{BH}$ mechanism $[12,28]$.

\subsubsection{Effect of reaction parameters on the reductive amination of 2-HTHP over the $\mathrm{Ni} / \mathrm{ZrO}_{2}$ catalyst}

Conventionally, the reductive amination of aldehydes or ketones involves several consequent reactions, including the condensation of the $\mathrm{C}=0$ group with ammonia or amino groups to form an imine or enamine intermediate, and the subsequent hydrogenation of the imine or enamine group to generate amine [2]. There are also many competitive reactions to generate byproducts, including the direct hydrogenation of the $\mathrm{C}=\mathrm{O}$ group to form an alcohol, or the overalkylation reactions toward the di- and tri-alkylamine groups [2]. Therefore, the efficient synthesis of amines from aldehydes or ketones highly depends on the reaction parameters, besides the catalysts. To improve the reaction activity and also elucidate the reaction mechanism and pathways, the effects of the reaction parameters including temperature, $\mathrm{H}_{2}$ pressure, $\mathrm{NH}_{3}$ to 2-HTHP molar ratio, and time on the reductive amination of 2-HTHP over the $\mathrm{Ni} / \mathrm{ZrO}_{2}$ catalyst were investigated.

Fig. 5 shows the effect of the reaction temperature on the catalytic conversion and selectivity of $\mathrm{Ni} / \mathrm{ZrO}_{2}$ at $2 \mathrm{MPa} \mathrm{H}_{2}$. In the temperature range of $50-90{ }^{\circ} \mathrm{C}$, the reaction temperature had a slight influence on the 2-HTHP conversion, but it influenced the product selectivity noticeably. The conversion of 2-HTHP could reach $98.9 \%$ even at a low temperature $50{ }^{\circ} \mathrm{C}$ and then increased to $100 \%$ with further increasing temperature to $60^{\circ} \mathrm{C}$, indicating the high reactivity of 2-HTHP as mentioned above. The selectivity of 5-AP increased sharply from $38.5 \%$ at $50{ }^{\circ} \mathrm{C}$ to a maximum of $84.7 \%$ at $80{ }^{\circ} \mathrm{C}$, and then dropped slightly to $84.4 \%$ at $90{ }^{\circ} \mathrm{C}$. The selectivity toward 1,5 -PD decreased gradually from $3.4 \%$ at $50{ }^{\circ} \mathrm{C}$ to $1.8 \%$ at 90 ${ }^{\circ} \mathrm{C}$. Meanwhile, the selectivity toward 5-IP and 5-HPIP declined 


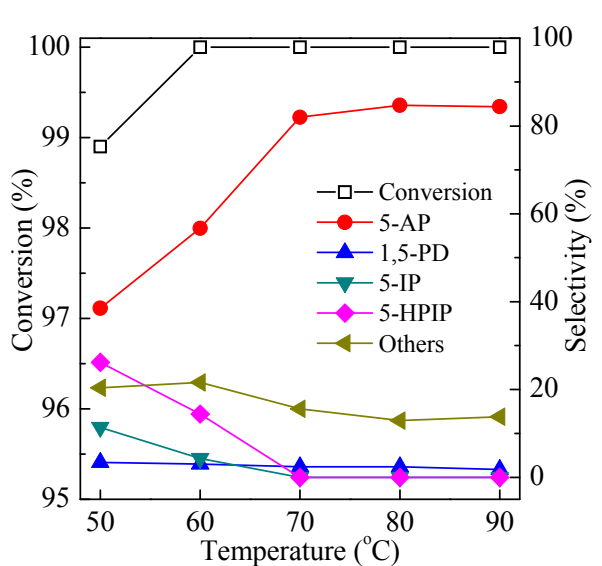

Fig. 5. Effect of the reaction temperature on the catalytic conversion and selectivity of $\mathrm{Ni} / \mathrm{ZrO}_{2}$. Reaction conditions: $15 \mathrm{~g}$ of $21.8 \% 2$-HTHP aqueous solution, $15 \mathrm{~g}$ of $25 \mathrm{wt} \%$ ammonia, $0.33 \mathrm{~g}$ of catalyst, $2 \mathrm{MPa} \mathrm{H}_{2}$, $1 \mathrm{~h}$.

drastically from $11.4 \%$ and $26.2 \%$ at $50{ }^{\circ} \mathrm{C}$ to 0 at temperatures $\geq 70{ }^{\circ} \mathrm{C}$, respectively, indicating that a high temperature favors the quick transformation of these products to the target product, 5-AP. The formation of more byproducts at a relatively high temperature of $90{ }^{\circ} \mathrm{C}$ accounts for the slight decrease in the 5-AP selectivity. Therefore, the above findings indicate that the high yield of 5-AP (> 84\%) could be achieved in the reductive amination of 2-HTHP at a temperature of $80^{\circ} \mathrm{C}$.

Fig. 6 shows the influence of $\mathrm{H}_{2}$ pressure on the catalytic conversion and selectivity of the 2-HTHP reductive amination. When there was no $\mathrm{H}_{2}$ charged in the reactor, a high 2-HTHP conversion of $95.7 \%$ was obtained, while no 5-AP was generated, and the main detected product was 5 -IP with $24.7 \%$ selectivity, indicating that 2-HTHP could be converted to 5-IP without $\mathrm{H}_{2}$ via the amination reaction. The 2-HTHP conversion increased to $100 \%$ when the $\mathrm{H}_{2}$ pressure increased to $0.5 \mathrm{MPa}$ and above. The 5-AP selectivity increased significantly to $79.1 \%$ at $0.5 \mathrm{MPa}$, peaked at $2 \mathrm{MPa} \mathrm{H}_{2}$ with an $84.7 \%$ selectivity, and then slightly decreased to $83.1 \%$ at $4 \mathrm{MPa}$. The selectivity of 5-IP dropped to 0 when the $\mathrm{H}_{2}$ pressure was $\geq 0.5 \mathrm{MPa}$, showing the high reactivity of such a product under $\mathrm{H}_{2}$ atmos-

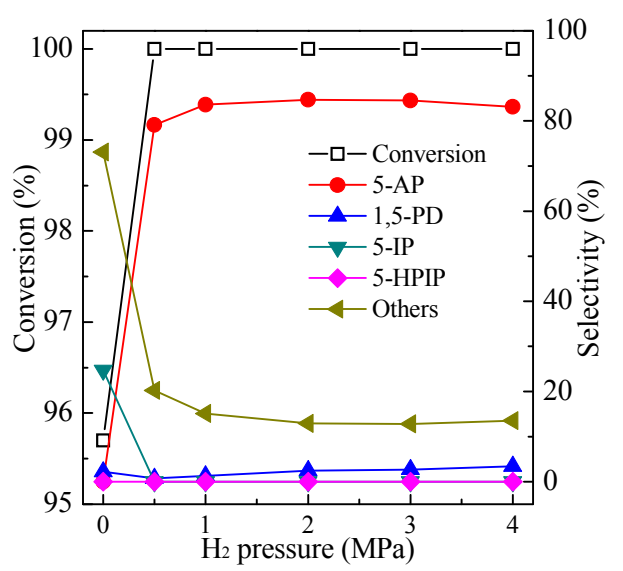

Fig. 6. Effect of $\mathrm{H}_{2}$ pressure on the catalytic conversion and selectivity of $\mathrm{Ni} / \mathrm{ZrO}_{2}$ at $80{ }^{\circ} \mathrm{C}$. Reaction conditions: $15 \mathrm{~g}$ of 21.8\% 2-HTHP aqueous solution, $15 \mathrm{~g}$ of $25 \mathrm{wt} \%$ ammonia, $0.33 \mathrm{~g}$ of catalyst $1 \mathrm{~h}$. phere. The 1,5-PD selectivity increased gradually from $0.7 \%$ to $3.4 \%$ with increasing the $\mathrm{H}_{2}$ pressure from 0.5 to $4 \mathrm{MPa}$, indicating that a high $\mathrm{H}_{2}$ pressure also favors the direct hydrogenation of 2-HTHP to 1,5-PD.

Fig. 7 displays the effect of the $\mathrm{NH}_{3} / 2$-HTHP molar ratio on the catalytic conversion and selectivity of $\mathrm{Ni} / \mathrm{ZrO}_{2}$ at $80{ }^{\circ} \mathrm{C}$ and $2 \mathrm{MPa} \mathrm{H}_{2}$. The 2-HTHP conversion was maintained at $100 \%$ irrespective of the $\mathrm{NH}_{3}$ to 2-HTHP molar ratio, while the selectivity toward 5-AP increased sharply from $63.2 \%$ to $90.8 \%$ with the increase in the $\mathrm{NH}_{3} / 2$-HTHP molar ratio from $2: 1$ to 12:1. This indicates that the high $\mathrm{NH}_{3}$ to 2 -HTHP molar ratio favors the conversion of 2-HTHP to the target 5-AP product. Meanwhile, the selectivity toward 1,5-PD gradually decreased from $6.8 \%$ to $1.4 \%$, and almost no 5-IP and 5-HPIP were detected. Obviously, the direct hydrogenation of 2-HTHP to 1,5-PD is a competitive reaction against the reductive amination of 2-HTHP. It has been reported that increasing the amount of $\mathrm{NH}_{3}$ could inhibit the formation of secondary amine $[26,29]$. Thus, the generation of a large amount of di-1-pentanolamine byproduct is probably the main reason for the low selectivity toward 5-AP at a low $\mathrm{NH}_{3}$ to 2-HTHP molar ratio.

Fig. 8 shows the catalytic conversion and selectivity of $\mathrm{Ni} / \mathrm{ZrO}_{2}$ in the 2-HTHP reductive amination as a function of the reaction time. The 2-HTHP conversion reached $96.4 \%$ when the reaction temperature rose to $80{ }^{\circ} \mathrm{C}$ (reaction time recorded as $0 \mathrm{~min}$ ) and then increased to $100 \%$ at the reaction time of 10 min. This result confirmed the high reactivity of 2-HTHP. A small amount of 5-AP with 9.6\% selectivity was detected when the reaction temperature approached $80{ }^{\circ} \mathrm{C}$, and 5 -IP and 5-HPIP were the major products with 31.8 and $33.6 \%$ selectivities, respectively. The selectivity of 5-AP sharply increased to $84.3 \%$ at $60 \mathrm{~min}$, and then gradually increased to $87.8 \%$ as the time increased to $360 \mathrm{~min}$. In the meantime, the selectivities toward 5-IP and 5-HPIP quickly decreased to 0 after the $60 \mathrm{~min}$ reaction. The increase in the 5-AP selectivity at the expense of 5-IP and 5-HPIP demonstrated that 5-IP and 5-HPIP might be the intermediates for the formation of 5-AP. The selectivity toward 1,5-PD was maintained at a low level in the range of

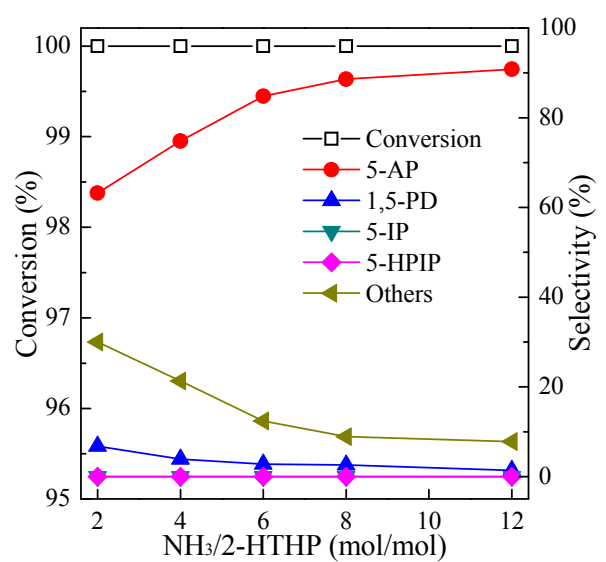

Fig. 7. Effect of the $\mathrm{NH}_{3} / 2$-HTHP molar ratio on the catalytic conversion and selectivity of $\mathrm{Ni} / \mathrm{ZrO}_{2}$. Reaction conditions: the amounts of $90 \%$ 2-HTHP, $25 \mathrm{wt} \%$ ammonia and DI water were varied to attain the desired $\mathrm{NH}_{3}$ to 2 -HTHP molar ratio, $0.33 \mathrm{~g}$ of catalyst, $80^{\circ} \mathrm{C}, 1 \mathrm{~h}$. 


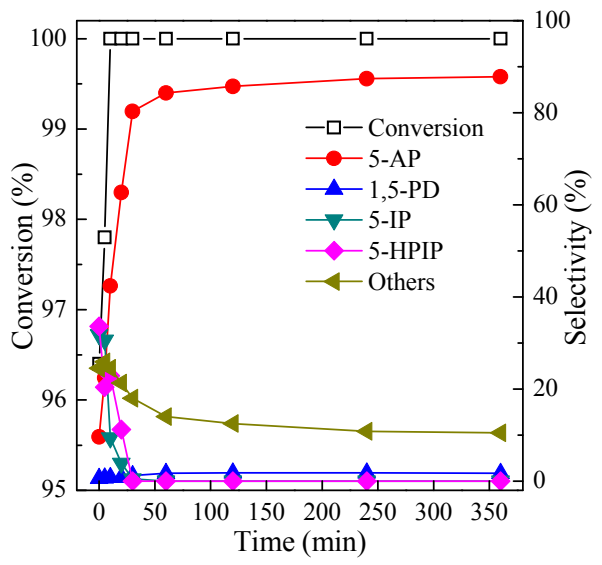

Fig. 8. Effect of the reaction time on the catalytic conversion and selectivity of $\mathrm{Ni} / \mathrm{ZrO}_{2}$. Reaction conditions: 15 g 21.8\% 2-HTHP aqueous solution, $15 \mathrm{~g} 25 \%$ concentrated ammonia, $0.33 \mathrm{~g}$ catalyst, $2 \mathrm{MPa} \mathrm{H}_{2}, 80$ ${ }^{\circ} \mathrm{C}$

$0.7-1.8 \%$ with increasing the reaction time to $360 \mathrm{~min}$. This indicates that it might be a stable byproduct, which could not be converted to other products under the reaction conditions.

\subsubsection{Reaction stability of the $\mathrm{Ni} / \mathrm{ZrO}_{2}$ catalyst in the 2-HTHP reductive amination}

The stability of the selected $\mathrm{Ni} / \mathrm{ZrO}_{2}$ catalyst was investigated using a continuous flow reactor, and the result is shown in Fig. 9. As can be seen, the conversion of 2-HTHP was maintained at $100 \%$ during the $90 \mathrm{~h}$ time-on-stream. The selectivity toward 5-AP was maintained at $\sim 83 \%$ during the initial $22 \mathrm{~h}$ and slowly decreased to $\sim 67 \%$ after a 90 -h time-on-stream. Almost no 5-IP and 5-HPIP were formed during the initial $22 \mathrm{~h}$; their selectivities gradually increased to $3.8 \%$ and $11.2 \%$, respectively, after a $36-\mathrm{h}$ reaction, and then remained nearly unchanged. The selectivity of 1,5-PD was maintained around 1.1\% during the 90-h time-on-stream.

The slow decrease in the 5-AP selectivity during the time-on-stream indicates the gradual deactivation of the cata-

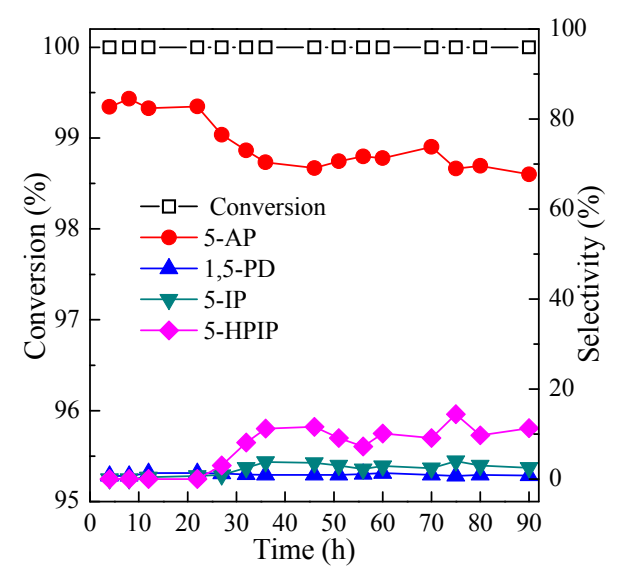

Fig. 9. Reduction amination of $2-\mathrm{HTHP}$ with $\mathrm{Ni} / \mathrm{ZrO}_{2}$ in a continuous flow reactor. Reductive amination of $2-\mathrm{HTHP}$ with $\mathrm{Ni} / \mathrm{ZrO}_{2}$ in a continuous flow reactor. Reaction conditions: mixed solution of $21.8 \mathrm{wt} \%$ 2-HTHP aqueous solution and $25 \mathrm{wt} \%$ concentrated ammonia at a weight ratio of $1: 1,80{ }^{\circ} \mathrm{C}, 3 \mathrm{MPa} \mathrm{H}_{2}$, WHSV of 2 - $\mathrm{HTHP}=0.5 \mathrm{~h}^{-1}$, and $\mathrm{H}_{2} / 2$-HTHP molar ratio $=30$. lyst, and the deactivation rate is calculated to be $\sim 19 \%$ after 90 h. To elucidate the possible reasons for the deactivation of the catalyst, the used catalyst after the 90-h reaction was characterized by TEM, XRD, and TG. No appreciable sintering of active particles can be observed in the TEM image of the used catalyst (Fig. S2). The XRD result (Fig. S3) showed no noticeable change in the catalyst structure after the reaction, and the $\mathrm{Ni}^{0}$ crystallite size slightly increased to $15.3 \mathrm{~nm}$. In addition, no remarkable weight loss due to the desorption/decomposition of coke was observed from the TG profile (Fig. S4). These findings excluded the Ni particles sintering and coke formation as the major reasons for the deactivation. ICP analysis of the collected reaction product showed a noticeable $\mathrm{Ni}$ leaching of $4.3 \mu \mathrm{g} / \mathrm{g}$, which would be one of the reasons for the deactivation. Note that the surface oxidation of the active $\mathrm{Ni}^{0}$, caused by the dissolved oxygen in the reactant, may also considerably result in the deactivation of the catalyst. However, no firm conclusion could be drawn on this because the oxidation of the used catalyst during the preparation of the sample for XPS measurement (Fig. S5) cannot be excluded.

\subsection{Reaction pathways and Structure-activity relationship}

Based on the reaction parameter studies, we propose the reaction pathway for the synthesis of 5-AP and the byproducts as shown in Scheme 3. Firstly, 2-HTHP is equilibrated with its ring-opened tautomer (5-HP) [17], which is then rapidly condensed with $\mathrm{NH}_{3}$ to form the reactive imine intermediate (5-IP). Imines are reported to be the key intermediates in the amination of both alcohols and carbonyl compounds for the synthesis of primary amines [2,11,26,30-32]. The 5-IP intermediate is readily hydrogenated to the target 5-AP product over metallic active sites in the presence of sufficient $\mathrm{H}_{2}$. The terminal amino group in 5-AP could condense with the $\mathrm{C}=0$ group in 5-HP to generate the secondary imine (5-HPIP). Note that 5-AP could also react with 5-IP to generate the intermediate, 5-HPIP, by the release of one $\mathrm{NH}_{3}$ molecule, which is similar to the generation of N-benzylidenebenzylamine from benzylamine and phenylmethanimine [26]. The 5-HPIP intermediate can be further transformed to 5-AP in the presence of excess $\mathrm{NH}_{3}$ and $\mathrm{H}_{2}$. The hydrogenation of 5-HP and 5-HPIP in the presence of $\mathrm{H}_{2}$ and active metal can produce the 1,5-PD and di-1-pentanolamine byproducts, respectively.

As can be seen from Scheme 3, high $\mathrm{NH}_{3}$ to 2-HTHP molar ratios favor the synthesis of the target product (5-AP) by promoting not only the condensation of the in situ generated 5-HP

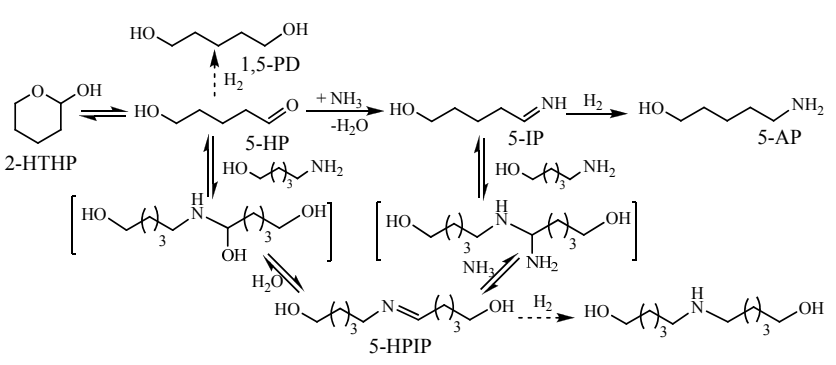

Scheme 3. Proposed reaction pathway for the synthesis of 5-AP and the main byproducts. 
with ammonia but also the transformation of the 5-HPIP intermediate into 5-AP, as exactly indicated in Fig. 7. $\mathrm{H}_{2}$ is indispensable for the reductive amination of 2-HTHP as one $\mathrm{H}_{2}$ molecule was consumed in the reduction of 5-IP to 5-AP. The direct hydrogenation of 5-HP to 1,5-PD and hydrogenation of 5-HPIP to di-1-pentanolamine are competitive reactions against the hydrogenation of 5-IP to 5-AP; consequently, a moderate $\mathrm{H}_{2}$ pressure in the range of 2-3 MPa is beneficial for the production of 5-AP, while a high $\mathrm{H}_{2}$ pressure (e.g., $>3 \mathrm{MPa}$, Fig. 6) results in relatively high byproduct yields of 1,5-PD and di-1-pentanolamine.

Because 5-HP could readily react with $\mathrm{NH}_{3}$ to form 5-IP (Table 2, entry 1, Fig. 8), the hydrogenation of 5-IP to 5-AP is proposed to be the rate-determining step. A recent study by Zhang et al. [33] also indicated that the hydrogenation of imines was the rate-determining step involved in the one-pot reductive amination of carbonyl compounds with nitro compounds. Evidently, the hydrogenation activity of the metal catalysts played a key role in obtaining a high 5-AP yield. The hydrogenation activity of metal catalysts depends on the intrinsic property of the metal, as shown in Table 2, and on the number of active metal sites that is available. In our cases, a high 5-AP yield ( $>$ 80\%) was attained over supported $\mathrm{Ni}$ catalysts, particularly over $\mathrm{Ni} / \mathrm{ZrO}_{2}$, under mild conditions of $80{ }^{\circ} \mathrm{C}$ and $2 \mathrm{MPa} \mathrm{H}_{2}$ (Table 2). Considering that $\mathrm{Ni} / \mathrm{ZrO}_{2}$ had a relatively large $\mathrm{H}_{2}$ consumption (Fig. 3), the high reducibility of this catalyst may contribute to the relatively high 5-AP yield as more $\mathrm{Ni}^{2+}$ species could be reduced to active $\mathrm{Ni}^{0}$ prior to the reductive amination reaction. It has been reported that the condensation of carbonyl groups and $\mathrm{NH}_{3}$ or amino groups to form imine intermediates could be enhanced by the acidity of the catalyst $[9,25]$. The relatively large acidic site density of the $\mathrm{Ni} / \mathrm{ZrO}_{2}$ catalyst (Table 1) may also contribute to its relatively high performance in the synthesis of 5-AP from 2-HTHP.

\section{Conclusions}

We reported an efficient method for the synthesis of useful 5-amino-1-pentanol (5-AP) from biomass-derived dihydropyran by coupling the in situ generation of 5-hydroxypentanal (5-HP) and its reductive amination over supported Ni catalysts. The $\mathrm{Ni} / \mathrm{ZrO}_{2}$ catalyst was found to exhibit the highest 5-AP yield among several oxide supports, including $\mathrm{SiO}_{2}, \mathrm{TiO}_{2}, \mathrm{ZrO}_{2}$, $\gamma-\mathrm{Al}_{2} \mathrm{O}_{3}$, and $\mathrm{MgO}$ loaded Ni catalysts, as well as a serial of commercial hydrogenation catalysts, including $\mathrm{CuCr}_{2} \mathrm{O}_{4}$, Raney $\mathrm{Ni}$, and the carbon-supported noble metals of $\mathrm{Ru}, \mathrm{Pd}, \mathrm{Pt}$, and $\mathrm{Rh}$. A $90.8 \%$ yield of 5-AP was obtained in a batch reactor over $\mathrm{Ni} / \mathrm{ZrO}_{2}$ catalyst in the reductive amination of 2-HTHP under mild conditions of $80{ }^{\circ} \mathrm{C}$ and $2 \mathrm{MPa} \mathrm{H}_{2}$. The catalyst also presented an $83 \%$ 5-AP yield from 2-HTHP solution in a continuous flow reactor, and maintained $81 \%$ of its activity after a $90-\mathrm{h}$ time-on-stream. The characterization results showed that the $\mathrm{Ni} / \mathrm{ZrO}_{2}$ catalyst exhibited high reducibility and a high surface acid density, which are suggested to account for its relatively high activity and selectivity.

\section{Acknowledgments}

This work was supported by the National Natural Science Foundation of China (21872155, 21473224), Cooperation Foundation of Dalian National Laboratory for Clean Energy (DNL 180303), Key Research Project of Frontier Science of Chinese Academy of Sciences (QYZDJ-SSW-SLH051), the Youth Innovation Promotion Association, CAS (2016371), and the Suzhou Science and Technology Development Plan (SYG201626).

\section{References}

[1] V. Froidevaux, C. Negrell, S. Caillol, J. P. Pascault, B. Boutevin, Chem. Rev., 2016, 116, 14181-14224.

[2] M. Pelckmans, T. Renders, S. Van de Vyver, B. F. Sels, Green Chem., 2017, 19, 5303-5331.

[3] R. V. Jagadeesh, K. Murugesan, A. S. Alshammari, H. Neumann, M.-M. Pohl, J. Radnik, M. Beller, Science, 2017, 358, 326-332.

[4] M. Pera-Titus, F. Shi, ChemSusChem, 2014, 7, 720-722.

[5] Y. Xu, X. Jia, J. Ma, J. Gao, F. Xia, X. Li, J. Xu, Green Chem., 2018, 20, 2697-2701

[6] G. Hahn, P. Kunnas, N. de Jonge, R. Kempe, Nat. Catal., 2019, 2, 71-77.

[7] H. Yuan, J. P. Li, F. Su, Z. Yan, B.T. Kusema, S. Streiff, Y. Huang, M. Pera-Titus, F. Shi, ACS Omega, 2019, 4, 2510-2516.

[8] M. Pelckmans, W. Vermandel, F. Van Waes, K. Moonen, B. F. Sels, Angew. Chem. Int. Ed., 2017, 56, 14540-14544.

[9] G. Liang, A. Wang, L. Li, G. Xu, N. Yan, T. Zhang, Angew. Chem. Int. Ed., 2017, 56, 3050-3054.

[10] J. Niemeier, R.V. Engel, M. Rose, Green Chem., 2017, 19, 2839-2845

[11] Y. Li, H. Cheng, C. Zhang, B. Zhang, T. Liu, Q. Wu, X. Su, W. Lin, F. Zhao, Sci. China Chem., 2017, 60, 920-926.

[12] S. Li, M. Wen, H. Chen, Z. Ni, J. Xu, J. Shen, J. Catal., 2017, 350, 141-148.

[13] D. Pingen, C. Müller, D. Vogt, Angew. Chem. Int. Ed., 2010, 49, 8130-8133.

[14] M. Zheng, J. Pang, R. Sun, A. Wang, T. Zhang, ACS Catal., 2017, 7, 1939-1954.

[15] D. Sun, S. Sato, W. Ueda, A. Primo, H. Garcia, A. Corma, Green Chem., 2016, 18, 2579-2597.

[16] C. Li, H. Cai, B. Zhang, W. Li, G. Pei, T. Dai, A. Wang, T. Zhang, Chin. J. Catal., 2015, 36, 1638-1646.

[17] Z. J. Brentzel, K. J. Barnett, K. Huang, C. T. Maravelias, J. A. Dumesic, G. W. Huber, ChemSusChem, 2017, 10, 1351-1355.

[18] K. J. Barnett, D. J. McClelland, G. W. Huber, ACS Sustainable Chem. Eng., 2017, 5, 10223-10230.

[19] B. Q. Li, X. Q. Jiang, S. Q. Chen, Fine Chem. Intermed., 2014, 44, 40-42.

[20] S. Qiu, X. Zhang, Q. Liu, T. Wang, Q. Zhang, L. Ma, Catal. Commun., 2013, 42, 73-78.

[21] Z. Huang, K. J. Barnett, J. P. Chada, Z. J. Brentzel, Z. Xu, J. A. Dumesic, G. W. Huber, ACS Catal., 2017, 7, 8429-8440.

[22] Z. Huang, J. Chen, Y. Jia, H. Liu, C. Xia, H. Liu, Appl. Catal. B, 2014, 147, 377-386.

[23] X. Jia, X. Zhang, N. Rui, X. Hu, C. Liu, Appl. Catal. B, 2019, 244, 159-169.

[24] C. García-Sancho, R. Guil-López, A. Sebastián-López, R. M. Navarro, J. L. G. Fierro, Int. J. Hydrogen Energy, 2018, 43, 9607-9621.

[25] C. Xie, J. Song, H. Wu, Y. Hu, H. Liu, Z. Zhang, P. Zhang, B. Chen, B. Han, J. Am. Chem. Soc., 2019, 141, 4002-4009.

[26] Y. Zhang, H. Yang, Q. Chi, Z. Zhang, ChemSusChem, 2019, 12, 


\section{Graphical Abstract}

Chin. J. Catal., 2020, 41: 631-641 doi: S1872-2067(19)63471-6

Effective synthesis of 5-amino-1-pentanol by reductive amination of biomass-derived 2-hydroxytetrahydropyran over supported Ni catalysts

Xuemei Li, Junying Tian, Hailong Liu, Congkui Tang, Chungu Xia, Jing Chen *, Zhiwei Huang * Lanzhou Institute of Chemical Physics, Chinese Academy of Sciences

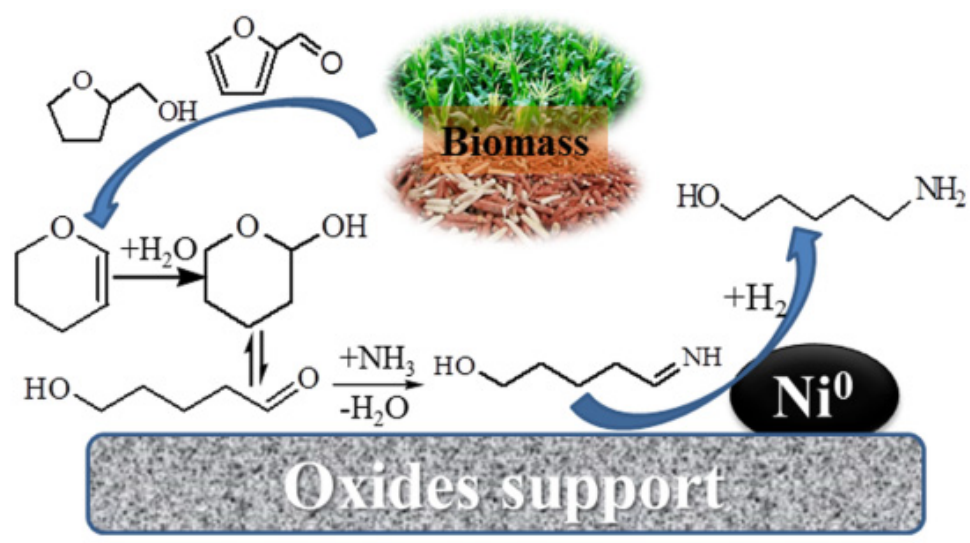

5-amino-1-pentanol was synthesized efficiently from biomass-derived dihydropyran by coupling the in situ generation of 5-hydroxypentanal and its reductive amination over supported $\mathrm{Ni}$ catalysts under mild reaction conditions.

1246-1255.

[27] G. Chieffi, M. Braun, D. Esposito, ChemSusChem, 2015, 8, 3590-3594.

[28] A. Tomer, Z. Yan, A. Ponchel, M. Pera-Titus, J. Catal., 2017, 356, 133-146.

[29] M. Chatterjee, T. Ishizaka, H. Kawanami, Green Chem., 2016, 18, 487-496.
[30] C. R. Ho, V. Defalque, S. Zheng, A. T. Bell, ACS Catal., 2019, 9, 2931-2939.

[31] K.-I. Shimizu, K. Kon, W. Onodera, H. Yamazaki, J. N. Kondo, ACS Catal., 2013, 3, 112-117.

[32] L. Ma, L. Yan, A.-H. Lu, Y. Ding, Chin. J. Catal., 2019, 40, 567-579.

[33] P. Zhou, C. Yu, L. Jiang, K. Lv, Z. Zhang, J. Catal., 2017, 352, 264-273.

\section{负载型Ni催化剂高效催化2-羟基四氢吡喃还原胺化制备5-氨基-1-戊醇}

李雪梅 ${ }^{\dagger}$, 田俊英 ${ }^{\dagger}$, 刘海龙, 唐从奎, 夏春谷, 陈 静 ${ }^{*}$, 黄志威 ${ }^{*}$ 中国科学院兰州化学物理研究所, 羊基合成与选择氧化国家重点实验室, 苏州研究院, 甘肃兰州730000

摘要: 伯胺等含氮化合物是最重要的化工中间体之一, 被广泛应用于聚合物、医药、农药、染料和表面活性剂等产品的生 产. 当前, 商业化伯胺主要通过卤代烃或环氧化合物直接胺化以及腈类或酰胺类化合物加氢制备, 这些过程受具有特定官 能团的有机原料短缺以及产生较多废物等问题的限制, 导致其生产成本较高. 因此, 高效可持续生产伯胺化合物路径的开 发得到了广泛关注. 醛和酮类化合物直接与氨还原胺化反应所需温度一般较低 $\left(\leq 120^{\circ} \mathrm{C}\right)$, 为伯胺的高选择性合成提供了 一个重要途径. 基于此, 本文利用2-羟基四氢吡喃能够原位转化为其互变异构体5-羟基戊醛, 而5-羟基戊醛中醛基具有较 高还原胺化活性的特征, 发展了一种以生物糠醛衍生二氢吡喃为原料, 通过先水合得到2-羊基四氢吡喃再在温和条件下还 原胺化合成 5-氨基-1-戊醇的新方法. 5-氨基-1-戊醇是一种分子中同时含有羟基和氨基的重要双官能团化合物,广泛用于 医药和农药合成, 也常被用作有机合成砌块, 目前其主要用途是合成具有很高药用价值的生物碱Manzamine A. 5-氨基-1戊醇的一条传统合成路线是以石化基 1,5 -戊二醇经浓盐酸进行单氯取代制备5-氯戊醇中间体, 该中间体经分离后再与氨气 反应制得5-氨基-1-戊醇的方法. 该方法原料成本高, 产生大量废弃物, 且只取得中等目标产物收率(66.6\%).

本文重点研究了不同氧化物载体包括 $\mathrm{SiO}_{2}, \mathrm{TiO}_{2}, \gamma-\mathrm{Al}_{2} \mathrm{O}_{3}, \mathrm{ZrO}_{2}$ 和 $\mathrm{MgO}$ 负载 $\mathrm{Ni}$ 催化剂的2-羟基四氢吡喃还原胺化性能, 并对比考察了 $\mathrm{CuCr}_{2} \mathrm{O}_{4}$, 雷尼 $\mathrm{Ni}, \mathrm{Ru} / \mathrm{C}, \mathrm{Pd} / \mathrm{C}, \mathrm{Pt} / \mathrm{C}$ 和Rh/C等商业加氢催化剂的性能. 研究发现, $\mathrm{ZrO}_{2}$ 负载 $\mathrm{Ni}$ 催化剂的活性高 于其他氧化物载体负载 $\mathrm{Ni}$ 催化剂的活性, 也明显优于所对比的系列商业加氢催化剂. 系列物理化学表征结果显示, $\mathrm{Ni} / \mathrm{ZrO}_{2}$ 催化剂同时表现出较高的还原性和表面酸密度, 这可能是该催化剂表现出最高5-氨基-1-戊醇收率的原因. 以 $\mathrm{Ni} / \mathrm{ZrO}_{2}$ 为催 
化剂, 于 $80{ }^{\circ} \mathrm{C}, 2 \mathrm{MPa} \mathrm{H}_{2}$ 条件下在间歇式反应器中催化2-羊基四氢吡喃水溶液还原胺化可取得 $90.8 \%$ 的 5-氨基-1-戊醇收率. 通过固定床反应器研究了 $\mathrm{Ni} / \mathrm{ZrO}_{2}$ 催化剂稳定性, 发现 5-氨基-1-戊醇初始收率可达 $83 \%$, 反应 $90 \mathrm{~h}$ 活性缓慢下降至初活性的 $81 \%$. Ni流失和表面氧化可能是催化剂的失活的主要原因. 通过对反应温度、 $\mathrm{H}_{2}$ 压力、2-羊基四氢吡喃/ $\mathrm{NH}_{3}$ 摩尔比等因素 对反应活性调变规律的探究, 推测2-羟基四氢吡喃催化还原胺化制备5-氨基-1-戊醇反应机理如下: 首先, 受化学平衡作用, 2-羟基四氢吡喃逐渐转化为其互变异构体5-羟基戊醛; 然后, 5-羟基戊醛中醛基迅速与 $\mathrm{NH}_{3}$ 反应生成亚胺中间体; 最后, 亚 胺中间体在金属催化剂上加氢得到5-氨基-1-戊醇.

关键词: Ni催化剂; 还原胺化; 二氢吡喃; 5-氨基-1-戊醇; 构效关系

收稿日期: 2019-09-01. 接受日期: 2019-10-10. 出版日期: 2020-04-05.

*通讯联系人. 电话: (0731)4968068; 电子信箱: chenj@licp.cas.cn

\#通讯联系人. 电话: (0731)4968070; 电子信箱: zwhuang@licp.cas.cn

$\dagger$ 共同第一作者.

基金来源：国家自然科学基金(21872155, 21473224); 中国科学院洁净能源创新研究院合作基金(DNL 180303); 中国科学院前沿 科学重点研究项目(QYZDJ-SSW-SLH051); 中国科学院青年创新促进会(2016371); 苏州科技发展计划项目(SYG201626).

本文的电子版全文由Elsevier出版社在ScienceDirect上出版(http://www.sciencedirect.com/science/journal/18722067). 